\title{
PENDAPATAN DAN NILAI TAMBAH AGROINDUSTRI TEMPE DI KECAMATAN PUNGGUR KABUPATEN LAMPUNG TENGAH
}

\author{
(Analysis of Income and Added Value of Tempe Agroindustry in Punggur Subdistrict \\ Central Lampung Regency
}

Viona Pramayang, Dwi Haryono, Ktut Murniati

Jurusan Agribisnis, Fakultas Pertanian, Universitas Lampung, Jl. Prof. Dr. Soemantri Brojonegoro No.1 Bandar Lampung 35141, E-mail: dwi.haryono@fp.unila.ac.id

\begin{abstract}
This study aims to analyze the level of income and added value of tempe agroindustry. This study uses a case study method. The research location is chosen purposively in Punggur Subdistrict, Central Lampung Regency, with the consideration that Punggur Subdistrict has the highest number of tempe producers in Central Lampung Regency. The samples were chosen by accidental sampling method in three villages. The number of respondents are 42 respondents. The data used in this study are primary and secondary data. The results showed that the tempe agroindustry in Punggur Subdistrict, Central Lampung Regency was profitable and feasible because of $R / C>1$ and positive added value.
\end{abstract}

Key words: added value, agroindustry, income, tempe

\section{PENDAHULUAN}

Pada umumnya, kedelai merupakan sumber protein nabati paling populer bagi masyarakat Indonesia. Tanaman kedelai menyebar hampir secara merata di seluruh wilayah Indonesia salah satunya yaitu Provinsi Lampung, meskipun Provinsi Lampung bukan merupakan sentra penghasil kedelai di Indonesia. Hal ini disebabkan oleh ketidaksesuaian lahan dan iklim dalam mengembangkan tanaman kedelai (Wirakusuma dan Sari 2005). Hingga saat ini, kedelai masih merupakan bahan utama untuk pembuatan tempe (Sarwono 2005).

Kabupaten Lampung Tengah merupakan satusatunya kabupaten yang mengalami kenaikan produktivitas sebesar 0,08 persen, sedangkan untuk produksi mengalami penurunan sebesar 1,47 persen. Penurunan produksi tersebut disebabkan oleh iklim yang tidak sesuai dengan tanaman kedelai serta lahan kedelai yang semakin berkurang. Penurunan produksi kedelai di Kabupaten Lampung Tengah menyebabkan para produsen tempe mengalami kesulitan dalam mendapatkan kedelai sebagai bahan baku utama, sehingga dalam mengatasi masalah tersebut para produsen tempe harus mengimpor dari negara lain seperti China dan Amerika. Selain sulitnya mencari kedelai, para produsen tempe juga mengeluh mengenai harga kedelai yang selalu berfluktuasi, walaupun harga yang berfluktuasi tersebut tidak terlalu besar selisihnya, namun akan mempengaruhi terhadap biaya total produksi yang mereka keluarkan dalam proses pembuatan tempe. Proses pembuatan tempe yang sangat mudah menyebabkan masyarakat banyak yang berprofesi sebagai pengrajin tempe dengan memanfaatkan kedelai yang ada. Jumlah agroindustri tempe di Provinsi Lampung sebanyak 3.463 orang dengan kebutuhan kedelai sebanyak $4.604 .046 \mathrm{~kg}$ per bulan yang tersebar di 12 kabupaten/kota di Provinsi Lampung (Organisasi Primkopti Provinsi Lampung 2017).

Kabupaten Lampung Tengah merupakan kabupaten yang memiliki jumlah produsen tempe terbanyak yaitu 667 orang. Agroindustri tempe di Kabupaten Lampung Tengah tersebar di berbagai kecamatan dan desa. Kecamatan Punggur merupakan kecamatan yang memiliki jumlah produsen terbanyak sebesar 69 orang yang tersebar di sembilan desa. Kecamatan Punggur dalam proses produksinya membutuhkan jumlah kedelai yang berbeda-beda yaitu berkisaran $300-2.012 \mathrm{~kg}$ per produksi. Para produsen tempe memanfaatkan kedelai impor yang ada di sekitar lokasi usaha untuk kegiatan pengolahan kedelai menjadi tempe. Hal tersebut dikarenakan produksi kedelai lokal tidak mampu mencukupi kebutuhan para produsen, serta kualitas kedelai impor lebih bagus dibandingkan kedelai lokal. Pengolahan merupakan suatu proses transformasi atau perubahan suatu bentuk komoditas menjadi suatu produk yang memiliki nilai tambah. Proses pengolahan kedelai menjadi tempe tersebut akan 
menghasilkan pendapatan bagi para produsen. Berdasarkan uraian tersebut, maka tujuan dari penelitian ini adalah untuk menganalisis tingkat pendapatan agroindustri tempe dan menganalisis nilai tambah agroindustri tempe di Kecamatan Punggur Kabupaten Lampung Tengah.

\section{METODE PENELITIAN}

Penelitian ini menggunakan metode studi kasus di Kecamatan Punggur Kabupaten Lampung Tengah yang dipilih secara sengaja (purposive) dengan pertimbangan bahwa Kecamatan Punggur memiliki jumlah produsen tempe terbanyak di Kabupaten Lampung Tengah. Populasi sasaran penelitian ini sebanyak 69 orang produsen tempe yang tersebar di sembilan desa. Pengambilan sampel menggunakan accidental sampling di tiga desa yang memiliki jumlah produsen terbanyak di Kecamatan Punggur yaitu Desa Sidomulyo, Punggur, dan Sidorahayu dengan total responden sebanyak 42 responden.

Data yang digunakan dalam penelitian ini adalah data primer dan sekunder. Data primer diperoleh dari hasil wawancara secara langsung kepada responden melalui pengamatan secara langsung dengan menggunakan daftar pertanyaan yaitu berupa kuisioner untuk mengetahui gambaran umum agroindustri tempe dan pendapatan. Data sekunder adalah data yang diperoleh dari literatur seperti Badan Pusat Statistik (BPS), lembaga/ instansi terkait, laporan-laporan, dan pustaka lainnya yang berhubungan dengan penelitian ini.

Metode analisis data yang digunakan pada penelitian ini adalah metode analisis deskriptif kuantitatif. Cara yang digunakan untuk menghitung pendapatan sama seperti yang dilakukan Sari, Haryono, dan Rosanti (2014).

$\pi=\mathrm{TR}-\mathrm{TC}$
$\pi=\mathrm{Y} . \mathrm{PY}-\sum \mathrm{Xi} . \mathrm{PXi}-\mathrm{BTT}$.

Keterangan:

$\pi \quad=$ Pendapatan $(\mathrm{Rp})$

$\mathrm{Y} \quad=$ Produksi tempe $(\mathrm{kg})$

Py $\quad=$ Harga tempe $(\mathrm{Rp})$

$\mathrm{Xi} \quad=$ Faktor produksi $(\mathrm{i}=1,2,3, \ldots \ldots, \mathrm{n})$

Pxi $=$ Harga faktor produksi ke-i $(\mathrm{Rp})$

$\mathrm{BTT}=$ Biaya tetap total $(\mathrm{Rp})$

Analisis data berikutnya adalah $\mathrm{R} / \mathrm{C}$ rasio untuk mengetahui kelayakan usaha pada agroindustri tempe yang dapat dirumuskan sebagai berikut :
$\mathrm{R} / \mathrm{C}=\mathrm{TR} / \mathrm{TC}$

Keterangan:

$\mathrm{R} / \mathrm{C}=$ Nisbah penerimaan dan biaya

$\mathrm{TR}=$ Total revenue atau penerimaan total $(\mathrm{Rp})$

$\mathrm{TC}=$ Total cost atau biaya total (Rp)

Kriteria pengambilan keputusan adalah:

1) Jika $R / C>1$, maka suatu usaha mengalami keuntungan.

2) Jika $\mathrm{R} / \mathrm{C}<1$, maka suatu usaha mengalami kerugian.

3) Jika $R / C=1$, maka suatu usaha mengalami impas.

Besarnya nilai tambah pada agroindustri tempe di Kecamatan Punggur dapat dihitung dengan menggunakan metode Hayami (Hayami 1987). Kriteria nilai tambah (NT) adalah sebagai berikut:

1) Jika NT $>0$, berarti pengembangan agroindustri tempe memberikan nilai tambah (positif).

2) Jika NT $<0$, berarti pengembangan agroindustri tempe tidak memberikan nilai tambah (negatif).

\section{HASIL DAN PEMBAHASAN}

\section{Karakteristik Responden Produsen Tempe}

Berdasarkan hasil penelitian, umur responden bervariasi antara 32 tahun sampai dengan 61 tahun. Tingkat pendidikan responden rata-rata yaitu SMP. Jumlah tanggungan keluarga produsen tempe berada pada kisaran 3-8 orang. Sebagian besar responden pada penelitian ini berjenis kelamin laki-laki.

\section{Pengadaan Bahan Baku}

Bahan baku kedelai diperoleh dari pasar-pasar yang ada di Kecamatan Punggur. Kisaran harga kedelai yang ada yaitu sebesar Rp7.200,00 - Rp7.500,00 per kg. Rata-rata jumlah kedelai yang digunakan agroindustri tempe per bulan yaitu $852,14 \mathrm{~kg}$ dengan harga rata-rata Rp7.321,43 per kg. Jenis kedelai yang digunakan pada agroindustri tempe di Kecamatan Punggur Kabupaten Lampung Tengah yaitu kedelai impor.

\section{Pengadaan Bahan Baku Penunjang}

Bahan baku penunjang atau bahan baku pendukung dalam agroindustri tempe adalah bahan-bahan yang digunakan dalam proses pengolahan yang berfungsi sebagai pelengkap dalam pembuatan tempe yaitu berupa ragi, kayu bakar, plastik pembungkus, dan minyak tanah. Total pengeluaran bahan penunjang dalam sebulan sebesar Rp517.296,98. Plastik 
merupakan bahan baku penunjang yang menyumbang biaya terbanyak yaitu sebesar Rp372.254,00 dan minyak tanah merupakan bahan baku penunjang yang menyumbang biaya paling sedikit yaitu sebesar Rp33.315,48.

\section{Penggunaan Peralatan}

Peralatan yang digunakan agroindustri tempe di Kecamatan Punggur Kabupaten Lampung Tengah umumnya masih sangat sederhana, bahkan terdapat peralatan yang berasal dari buatan sendiri seperti rak tempe, dan lampu sentir. Peralatan yang digunakan setiap agroindustri berbeda-beda, karena tidak semua agroindustri memiliki peralatan yang lengkap, seperti mesin pemecah biji kedelai dan mesin pompa. Penggunaan mesin pemecah biji kedelai juga masih sangat sedikit digunakan oleh para produsen, hal tersebut disebabkan harga mesin yang mahal.

\section{Tenaga Kerja}

Tenaga kerja yang ada di agroindustri tempe Kecamatan Punggur Kabupaten Lampung Tengah sebagian besar sudah berpengalaman, karena merupakan usaha turun temurun dari orang tua mereka. Tenaga kerja yang digunakan pada agroindustri tempe di Kecamatan Punggur Kabupaten Lampung Tengah yaitu tenaga kerja yang berasal dari dalam keluarga dan dari luar keluarga. Rata-rata HOK dalam keluarga lebih besar bila dibandingkan dengan tenaga kerja luar keluarga. Agroindustri tempe di Kecamatan Punggur Kabupaten Lampung Tengah termasuk ke dalam agroindustri rumah tangga, karena jumlah tenaga kerja yang digunakan rata-rata empat orang.

\section{Produksi Tempe}

Agroindustri tempe di Kecamatan Punggur Kabupaten Lampung Tengah memproduksi empat jenis produk tempe yaitu produk A $(\mathrm{Rp} 500,00)$ berukuran $6 \mathrm{~cm}$, produk B (Rp1.000,00) berukuran $8 \mathrm{~cm}$, produk C (Rp2.000,00) berukuran $11 \times 12 \mathrm{~cm}$, dan produk D $(\mathrm{Rp} 4.000,00)$ berukuran $11 \times 20 \mathrm{~cm}$. Produksi tempe per bulan di agroindustri tempe Kecamatan Punggur Kabupaten Lampung Tengah secara lengkap disajikan pada Tabel 1.

Tabel 1 menunjukkan bahwa jumlah produksi tempe selama sebulan sebesar $1.448,72 \mathrm{~kg}$ menghasilkan 10.000,47 bungkus tempe. Produk B merupakan jumlah produk yang paling banyak dihasilkan oleh agroindustri tempe yaitu sebesar 687,50 kg. Hal tersebut dikarenakan masyarakat lebih menyukai produk $\mathrm{B}$, karena harga yang relatif murah yaitu Rp1.000,00 dan ukuran tempe yang tidak terlalu besar.

Pemilik agroindustri tempe tidak memisahkan jumlah kedelai dan jumlah bahan baku penunjang yang digunakan, karena pemisahan empat jenis tempe dilakukan ketika berada pada tahap pengemasan. Pada masing-masing jenis tempe tersebut tidak dapat diketahui jumlah kedelai dan jumlah bahan baku penunjang yang digunakan. Jumlah kedelai yang digunakan pada agroindustri tempe akan mencerminkan berapa banyak tempe per $\mathrm{kg}$ yang akan dihasilkan per masing-masing produk.

\section{Analisis Pendapatan}

Pendapatan merupakan hasil pengurangan dari penerimaan dengan biaya total. Pendapatan menunjukkan seluruh uang/hasil material lainnya yang dicapai dari penggunaan kekayaan atau jasa yang diterima oleh seseorang atau rumah tangga selama jangka waktu tertentu pada suatu kegiatan ekonomi (Winardi 1998). Pendapatan yang dihitung pada penelitian ini merupakan pendapatan agroindustri bulan Maret. Rata-rata pendapatan dan R/C rasio pada agroindustri tempe di Kecamatan Punggur Kabupaten Lampung Tengah selama satu bulan dapat dilihat pada Tabel 2 .

Tabel 2 menunjukkan bahwa penerimaan yang diperoleh rata-rata responden per bulan sebesar Rp11.905.281,63. Perhitungan analisis pendapatan dilihat dari segi pendapatan atas biaya tunai dan pendapatan atas biaya total. Pendapatan atas biaya tunai didapatkan angka sebesar Rp2.543.357,99 sedangkan pendapatan atas biaya total sebesar Rp1.939.725,12. Dilihat dari nisbah penerimaan (R/C rasio) terhadap biaya tunai dan biaya total rata-rata per bulan, maka diketahui bahwa agroindustri tempe di Kecamatan Punggur Kabupaten Lampung Tengah menguntungkan dan layak untuk dijalankan, karena nilai $\mathrm{R} / \mathrm{C}$ rasio yang diperoleh lebih dari satu.

Tabel 1. Produksi tempe per bulan di agroindustri tempe Kecamatan Punggur Kabupaten Lampung Tengah

\begin{tabular}{crr}
\hline Jenis Produk & \multicolumn{1}{c}{$\begin{array}{c}\text { Produksi } \\
(\mathrm{kg})\end{array}$} & \multicolumn{1}{c}{$\begin{array}{c}\sum \text { Tempe } \\
\text { (bungkus) }\end{array}$} \\
\hline Produk A & 152,38 & $3.047,62$ \\
Produk B & 687,50 & $4.583,33$ \\
Produk C & 365,95 & $1.829,76$ \\
Produk D & 242,89 & 539,76 \\
\hline Jumlah & $1.448,72$ & $10.000,47$ \\
\hline
\end{tabular}


Tabel 2. Rata-rata pendapatan dan R/C rasio pada agroindustri tempe di Kecamatan Punggur Kabupaten Lampung Tengah selama satu bulan

\begin{tabular}{|c|c|c|c|c|c|}
\hline \multirow{2}{*}{ No. } & \multirow{2}{*}{ Uraian } & \multicolumn{4}{|c|}{ Per Bulan } \\
\hline & & Satuan & Jumlah & Harga (Rp) & Nilai (Rp) \\
\hline \multirow[t]{2}{*}{1.} & Penerimaan & & & & \\
\hline & Produksi & $\mathrm{Kg}$ & $1.448,73$ & $8.217,76$ & $11.905 .281,63$ \\
\hline \multirow[t]{20}{*}{2.} & Biaya Produksi & & & & \\
\hline & a. Biaya Tunai & & & & \\
\hline & Biaya Variabel & & & & \\
\hline & Kedelai & $\mathrm{Kg}$ & $1.114,41$ & $7.321,43$ & $8.159 .083,67$ \\
\hline & Ragi & $\mathrm{Kg}$ & 1,62 & $23.440,48$ & $37.951,25$ \\
\hline & Kayu Bakar & Kubik & 4,33 & $64.404,76$ & $279.087,30$ \\
\hline & Plastik & $\mathrm{Kg}$ & 12,69 & $29.333,33$ & $372.253,97$ \\
\hline & Minyak Tanah & Liter & 2,61 & $14.500,00$ & $37.803,57$ \\
\hline & TKLK & HOK & 11,28 & $14.523,81$ & $163.763,36$ \\
\hline & Biaya Angkut & $\mathrm{Rp}$ & & & $290.909,09$ \\
\hline & Biaya Tetap & & & & \\
\hline & Biaya Listrik & $\mathrm{Rp}$ & & & $21.071,43$ \\
\hline & Total Biaya Tunai & $\mathrm{Rp}$ & & & $9.361 .923,64$ \\
\hline & b. Biaya Diperhitungkan & & & & \\
\hline & Biaya Variabel & & & & \\
\hline & TKDK & HOK & 37,50 & $14.523,81$ & $544.642,86$ \\
\hline & Biaya Tetap & & & & \\
\hline & Penyusutan & $\mathrm{Rp}$ & & & $58.990,01$ \\
\hline & Total Biaya Diperhitungkan & $\mathrm{Rp}$ & & & $603.632,87$ \\
\hline & Total Biaya & $\mathrm{Rp}$ & & & $9.965 .556,51$ \\
\hline \multirow[t]{3}{*}{3.} & Pendapatan & & & & \\
\hline & Pendapatan Atas Biaya Tunai & $\mathrm{Rp}$ & & & 2.543.357,99 \\
\hline & Pendapatan Atas Biaya Total & $\mathrm{Rp}$ & & & $1.939 .725,12$ \\
\hline \multirow[t]{3}{*}{4.} & $\mathrm{R} / \mathrm{C}$ Rasio & & & & \\
\hline & R/C Rasio Atas Biaya Tunai & $\mathrm{Rp}$ & & & 1,27 \\
\hline & R/C Rasio Atas Biaya Total & $\mathrm{Rp}$ & & & 1,19 \\
\hline
\end{tabular}

Nilai R/C atas biaya tunai sebesar 1,27 yang berarti bahwa setiap Rp10.000,00 yang dikeluarkan untuk usaha tempe ini, maka yang didapatkan oleh agroindustri adalah sebesar Rp12.700,00 sehingga dapat dikatakan bahwa agroindustri mendapatkan keuntungan sebanyak Rp12.700,00 atas biaya tunai. Untuk $\mathrm{R} / \mathrm{C}$ atas biaya total yang didapatkan sebesar 1,19 berarti bahwa setiap Rp10.000,00 yang dikeluarkan agroindustri, maka agroindustri tersebut mendapatkan keuntungan sebesar Rp11.900,00. Hasil penelitian ini sejalan dengan hasil penelitian Aldhariana, Lestari, dan Ismono (2016) mengenai analisis keragaan agroindustri beras siger. Hasil penelitian tersebut menunjukkan bahwa agroindustri Mekar Sari dan agroindustri Toga Sari juga menguntungkan dan layak diusahakan seperti halnya agroindustri tempe di Kecamatan Punggur Kabupaten Lampung Tengah.

\section{Analisis Nilai Tambah}

Analisis nilai tambah pada agroindustri tempe di Kecamatan Punggur Kabupaten Lampung Tengah ini dilakukan untuk melihat seberapa besar balas jasa yang diterima oleh tenaga kerja secara langsung. Perhitungan nilai tambah agroindustri dapat mengetahui besarnya sumbangan input lain yang diberikan dalam proses produksi tempe. Analisis nilai tambah yang dilakukan pada agroindustri tempe adalah analisis dalam kurun waktu satu bulan yaitu pada bulan Maret. Ratarata nilai tambah agroindustri tempe dapat dilihat pada Tabel 3. Tabel 3 menunjukkan bahwa nilai faktor konversi selama sebulan sebesar 1,30 artinya bahwa setiap satu $\mathrm{kg}$ kedelai yang diolah oleh agroindustri akan menghasilkan rata-rata tempe sebanyak $1,30 \mathrm{~kg}$. Produksi tempe menghasilkan koefisien tenaga kerja sebesar 0,04 yang menunjukkan bahwa banyaknya tenaga kerja yang digunakan agroindustri untuk mengolah tempe sebanyak satu kg kedelai sebesar 0,04 HOK. Selain itu juga, sumbangan input lain yang digunakan pada proses pengolahan tempe sebesar Rp985,33 yang artinya sumbangan input lain yang digunakan agroindustri sebesar $1 \mathrm{~kg}$ kedelai menjadi tempe yaitu sebesar Rp985,33. Dalam penelitian ini, nilai imbalan tenaga kerja yang diperoleh sebesar Rp635,68. 
Tabel 3. Rata-rata nilai tambah pada agroindustri tempe di Kecamatan Punggur Kabupaten Lampung Tengah selama satu bulan

\begin{tabular}{|c|c|c|c|}
\hline No. & Variabel & Nilai & Rata-rata \\
\hline \multicolumn{4}{|c|}{ Output, Input dan Harga } \\
\hline 1. & Output (kg/bulan) & A & $1.448,73$ \\
\hline 2. & Bahan Baku (kg/bulan) & B & $1.114,41$ \\
\hline 3. & Tenaga Kerja (HOK/bulan) & $\mathrm{C}$ & 48,78 \\
\hline 4. & Faktor Konversi & $\mathrm{D}=\mathrm{A} / \mathrm{B}$ & 1,30 \\
\hline 5. & Koefisien Tenaga Kerja & $\mathrm{E}=\mathrm{C} / \mathrm{B}$ & 0,04 \\
\hline 6. & Harga Output (Rp/kg) & $\mathrm{F}$ & $8.217,76$ \\
\hline 7. & Upah Rata-rata Tenaga Kerja(Rp/HOK) & $\mathrm{G}$ & $14.523,81$ \\
\hline \multicolumn{4}{|c|}{ Pendapatan dan Keuntungan (Rp/kg) } \\
\hline 8. & Harga Bahan Baku & $\mathrm{H}$ & $7.321,43$ \\
\hline & Sumbangan Input Lain & I & 985,33 \\
\hline 10. & Nilai Output & $\mathrm{J}=\mathrm{D} \times \mathrm{F}$ & $10.683,02$ \\
\hline & a. Nilai Tambah & $\mathrm{K}=\mathrm{J}-\mathrm{I}-\mathrm{H}$ & $2.376,26$ \\
\hline & b. Rasio Nilai Tambah & $L=(K / J) \times 100 \%$ & 22,24 \\
\hline & a. Imbalan Tenaga Kerja & $\mathrm{M}=\mathrm{E} \times \mathrm{G}$ & 635,68 \\
\hline & b. Bagian Tenaga Kerja & $\mathrm{N} \%=(\mathrm{M} / \mathrm{K}) \times 100 \%$ & 26,75 \\
\hline \multirow[t]{2}{*}{13.} & a. Keuntungan & $\mathrm{O}=\mathrm{K}-\mathrm{M}$ & $1.740,58$ \\
\hline & b. Tingkat Keuntungan & $\mathrm{P} \%=(\mathrm{O} / \mathrm{K}) \times 100 \%$ & 73,25 \\
\hline \multicolumn{4}{|c|}{ Balas Jasa Pemilik Faktor-Faktor Produksi } \\
\hline & Marjin Keuntungan & $\mathrm{Q}=\mathrm{J}-\mathrm{H}$ & $3.361,59$ \\
\hline & a. Keuntungan & $\mathrm{R}=\mathrm{O} / \mathrm{Q} \times 100 \%$ & 51,78 \\
\hline & b. Tenaga Kerja & $\mathrm{S}=\mathrm{M} / \mathrm{Q} \times 100 \%$ & 18,91 \\
\hline & c. Input Lain & $\mathrm{T}=\mathrm{I} / \mathrm{Q} \times 100 \%$ & 29,31 \\
\hline
\end{tabular}

Keuntungan yang diperoleh dari hasil pengolahan kedelai yaitu Rp1.740,58 dengan bagian keuntungan sebesar 73,25 persen dari nilai output.

Agroindustri tempe di Kecamatan Punggur Kabupaten Lampung Tengah masuk dalam agroindustri yang bersifat padat modal. Hal ini dapat dilihat dari besarnya nilai balas jasa pemilik terhadap keuntungan sebesar 51,78 lebih besar dibandingkan terhadap nilai tenaga kerja sebesar 18,91. Hasil penelitian ini sejalan dengan penelitian Arum, Widjaya, dan Marlina (2016) yang menunjukkan bahwa agroindustri tempe di Kabupaten Pringsewu bersifat padat modal, dilihat dari besarnya nilai balas jasa pemilik terhadap keuntungan yaitu sebesar 37,94 lebih besar dibandingkan nilai tenaga kerja yang hanya sebesar 15,63.

\section{KESIMPULAN}

Pendapatan atas biaya tunai pada agroindustri tempe di Kecamatan Punggur Kabupaten Lampung Tengah per bulan sebesar Rp2.543.357,99 dan pendapatan atas biaya total sebesar Rp1.939.725,12. Pendapatan pada kegiatan produksi agroindustri tempe di Kecamatan Punggur Kabupaten Lampung Tengah menguntungkan, jika dilihat dari nisbah penerimaan $(\mathrm{R} / \mathrm{C}$ rasio) terhadap biaya tunai maupun nisbah penerimaan ( $\mathrm{R} / \mathrm{C}$ rasio) atas biaya total lebih dari satu. Agroindusti tempe di Kecamatan Punggur Kabupaten Lampung Tengah dapat dikatakan menguntungkan, karena memiliki nilai tambah yang positif, sehingga layak untuk diusahakan.

\section{DAFTAR PUSTAKA}

Aldhariana SF, Lestari DAH, dan Ismono RH. 2016. Analisis keragaan agroindustri beras siger studi kasus pada agroindustri Toga Sari (Kabupaten Tulang Bawang) dan agroindustri Mekar Sari (Kota Metro). JIIA, 4 (3): 317-325. https://jurnal.fp.unila.ac.id/ index.php/JIA/article/view/1507/1361 [ 8 November 2017 ].

Arum WP, Widjaya S, dan Marlina L. 2017. Kelayakan usaha dan nilai tambah agroindustri tempe. JIIA, 5 (2): 124-133. http://jurnal.fp.unila.ac.id/index.php/JIA/arti cle/view/1649/1475. [ 8 November 2017 ].

Hayami Y. 1987. Agricultural Marketing and Processing in Upland Java : A Perspective From Sunda Village. CGPRT Centre. Bogor.

Kementerian Pertanian. 2017. Outlook Komoditas Pertanian Subsektor Tanaman Pangan Komoditas Kedelai. Pusat Data dan Sistem Informasi Pertanian. Jakarta. 
Organisasi Primkopti Provinsi Lampung. 2017. Perkembangan Agroindustri Tempe di Provinsi Lampung tahun 2017. Bandar Lampung. Lampung.

Sari DK, Haryono D, dan Rosanti N. 2014. Analisis pendapatan dan tingkat kesejahteraan rumah tangga petani jagung di Kecamatan Natar Kabupaten Lampung Selatan. JIIA, 2 (1) : 64-70. http://jurnal.fp.
unila.ac.id/index.php/JIA/article/view/562/5 24. [ 6 November 2017 ].

Sarwono. 2005. Membuat tempe dan oncom Cetakan 29. Penebar Swadaya. Jakarta.

Winardi. 1998. Pengantar Ilmu Ekonomi. Tarsito. Bandung.

Wirakusuma dan Sari E. 2005. Tempe makanan "Segar" asli Indonesia. Penebar Swadaya. Jakarta. 